\title{
PEMBERDAYAAN KELOMPOK WANITA TANI MELALUI PEMBUATAN KERIPIK SAYURAN METODE VACUUM FRYING
}

\author{
Hastin Ernawati Nur Chusnul Chotimah ${ }^{1 *}$, Wijantri Kusumadati ${ }^{2}$ \\ Eka Nor Taufik ${ }^{3}$, Sunainah ${ }^{4}$ \\ 1,2,3,4 Universitas Palangka Raya \\ e-mail : hastinwindarto@agr.upr.ac.id
}

\begin{abstract}
Petuk Katimpun is one of the supplier villages for vegetable needs in the Palangka Raya city and its surroundings. At the abundant harvest, the prices of vegetables dropped sharply and were even worthless. Vegetables are left to rot in the tree, because there are costs to be taken to pick the vegetables. This is certainly very painful for the farmer. The farmers continue to lose money. One solution is to increase the value added of vegetables through processing technology. The technology of processing vegetable chips with vacuum frying is able to maintain the distinctive aroma and color of vegetables, crisper texture, lower vitamin damage and lower oil absorption. The purpose of this community service program is to transfer vacuum frying technology to increase the value added of the vegetables so that the level of the loss of farmers can be reduced. The approach were taken by counseling, training and coaching and mentoring. The counseling was carried out by direct communication and interactive discussion, while training of using vacuum frying tools with various vegetable raw materials was carried out under the guidance of the service team. The coaching and group assistance were carried out in the acquisition of SPP-IRT as well as ways to access markets both directly and indirectly. The results of the community service program showed that $70 \%$ of partners were able to operate vacuum frying equipment. The capabilities of labeling and packaging were $100 \%$. They also had an ability to access markets indirectly through online media. The direct market could not be accessed due to the SPP-IRT certificate has not been obtained.
\end{abstract}

Key Words : community empowerment, vegetables chip, vacuum frying

\section{PENDAHULUAN}

Kelurahan Petuk Katimpun menjadi bagian dari kecamatan Jekan Raya kotamadya Palangka Raya. Petuk Katimpun hanya berjarak kurang lebih $11 \mathrm{~km}$ dari pusat kota Palangka Raya dan merupakan salah satu penghasil sayur mayur segar. Jenis-jenis sayuran yang dibudidayakan meliputi tomat, cabe, kacang panjang dan terong, sementara itu komoditas buahbuahan yang menjadi unggulan adalah melon, semangka, pisang dan pepaya. Pemasaran sayuran dan buah-buahan tersebut selain diambil pengepul dan dijual ke pasar, hasil-hasil pertanian tersebut juga sebagian dijual di pinggir-pinggir jalan trans Kalimantan dengan cara mendisplay di gubug-gubug kecil semi permanen milik petani pribadi maupun petani penyewa. Biasanya petani menjual produk sayuran dalam bentuk segar tanpa olahan mengingat sayuran 
ISSN : $2620-4665$ (print)

ISSN : 2620 - 4673 (online)

Website : http://jurnal.untan.ac.id/index.php/JPLP2KM

tidak bisa bertahan lama, sehingga petani tidak punya pilihan lain untuk menjual produk yang dihasilkan saat itu juga. Hal tersebut diperparah pada saat panen raya, hasil panen sayuran berlimpah sehingga tidak terserap pasar. Sayuran yang tidak terserap pasar tersebut biasanya hanya digunakan sebagai pakan ternak, dibiarkan tetap di pohonnya atau bahkan dibiarkan membusuk yang nantinya digunakan sebagai pupuk hijau. Menurut Sujiati - Ketua Kelompok Wanita Tani (KWT) Bunga Tanjung - harga kacang panjang, misalnya, hanya dihargai Rp. 1.000 per kilogramnya, mentimun Rp. 500 dan tomat Rp. 1.500, padahal dalam satu kali panen kacang panjang mencapai $100 \mathrm{~kg}$, timun 2 kuintal serta tomat mencapai 2 pikul ( 1 pikul $=100 \mathrm{~kg}$ ) per 0,2 Ha. Anjloknya harga sayuran serta tidak terserapnya beberapa komoditas tersebut di pasaran dirasakan sangat menyakitkan bagi petani dikarenakan biaya yang harus dikeluarkan untuk membongkar seluruh tanaman tersebut tidaklah sedikit. Ketergantungan petani terhadap tengkulak juga sangat tinggi. Hampir sebagian besar petani menjual produk sayurnya kepada tengkulak. Kondisi ini tentu saja mempengaruhi tingkat pendapatan petani sayuran di Kelurahan Petuk Katimpun, sehingga dibutuhkan upaya tambahan untuk mengurangi tingkat kehilangan hasil produksi dan peningkatan nilai tambah dan jual produk.

Nilai tambah adalah pertambahan nilai suatu komoditas karena mengalami proses pengolahan, pengangkutan penyimpanan dalam suatu produksi. Disektor pertanian, penciptaan nilai tambah lebih banyak terjadi di sektor tengah (bukan ditingkat hulu) dari sistem agribisnis, yaitu pengolahan hasil pertanian (agroindustri). Hal ini disebabkan usaha di tingkat sektor tengah lebih menguasai teknologi penciptaan nilai-tambah dan akses pasar dibanding usaha ditingkat hulu (petani). Petani memang mempunyai kemampuan dalam budidaya pertanian dan mampu menghasilkan produksi dalam jumlah yang besar, tetapi banyak yang belum mampu menguasai teknologi pencipta nilai tambah dan kemampuan dalam mengakses pasar.Transfer teknologi yang pernah dilaksanakan oleh Pemerintah Daerah Kota Palangka Raya di KWT Petuk Ketimpun dalam hal peningkatan nilai tambah produk sayuran baru sebatas pembuatan keripik kelakai dan keripik bayam dengan teknologi penggorengan biasa (deep frying). Kelakai dan bayam dibalut menggunakan tepung kemudian digoreng menggunakan minyak goreng kemudian dikemas menggunakan plastik biasa. Transfer teknologi tersebut juga didukung dengan pemberian bantuan berupa sealer untuk mengemas keripik sayuran tersebut. Proses produksi keripik kelakai dan bayam tersebut masih berlangsung sampai sekarang walaupun tidak setiap hari atau tergantung pesanan. Berdasarkan kondisi penerapan teknologi tersebut serta hasil 
diskusi dengan KWT disepakati bahwa pada kegiatan PKM di KWT Petuk Ketimpun ini proses pembinaan dan pendampingan kepada petani sayuran dilakukan dengan memberikan pengetahuan dan keterampilan kepada mereka agar mampu menguasai teknologi pengolahan keripik sayuran menggunakan vacuum frying.

Pengolahan produk hortikultura menjadi keripik sayur dengan penggorengan vacuum mempunyai keuntungan dibandingkan dengan penggorengan biasa (deep frying) diantaranya dapat mempertahankan aroma dan warna yang khas dari sayuran, tekstur yang lebih renyah, kerusakan vitamin rendah, dan penyerapan minyak yang rendah. Metode penggorengan dengan cara vacuum frying ini relative mudah dan sederhana, karena menggunakan teknologi dan peralatan yang sederhana. Oleh karena itu, industri pengolahan keripik sayur ini dapat diterapkan di industri skala rumah tangga. Adanya industri ini, diharapkan dapat dijadikan usaha untuk meningkatkan nilai tambah sayuran produksi petani. Selain itu adanya industri keripik sayur ini juga dapat membantu menciptakan lapangan kerja, sehingga akan meningkatkan perekonomian masyarakat khususnya petani di Kelurahan Petuk Katimpun. Menurut Sucihatiningsih dkk, (2015), harga jual keripik terong dan wortel bisa mencapai Rp. 95.000 per kilogramnya dan campuran beberapa keripik sayuran yang dikemas menjadi satu dalam satu toples kecil bisa dijual dengan harga Rp. 38.000. Untuk mendapatkan 1 kg keripik sayuran, ratarata memerlukan sayur sebanyak $3 \mathrm{~kg}$. Selain itu keripik sayuran juga memiliki kandungan gizi yang sangat baik untuk kesehatan sehingga layak dikembangkan. Dengan usaha tersebut diharapkan mampu memperbaiki dan meningkatkan perekonomian petani sayur.

Keripik merupakan makanan yang mempunyai kadar air rendah atau $<3 \%$, sehingga umur penyimpanannya bisa lebih lama apabila dibandingkan dengan jenis makanan olahan basah lainnya. Keripik biasanya digunakan sebagai camilan atau makanan ringan yang digemari dari semua kalangan usia mulai dari anak-anak hingga orang tua. Peluang pasar keripik sayur sebagai panganan kering di Kota Palangka Raya masih terbuka dan prospektif, mengingat produk ini belum ada di pasaran. Di beberapa toko oleh-oleh dan swalayan hanya ada dijual keripik buah-buahan yang diproduksi di pulau Jawa. Diversifikasi produk berupa keripik sayuran ini diharapkan dapat meningkatkan konsumsi masyarakat terhadap sayuran, hal ini ditunjang dengan semakin meningkatnya kesadaran masyarakat akan pentingnya makanan sehat (healthy foods) yang banyak mengandung serat (dietary fiber). Peluang pasar keripik sayuran tersebut belum sepenuhnya diketahui oleh KWT Petuk Ketimpun. Pemasaran usaha keripik kelakai dan 
ISSN : $2620-4665$ (print)

ISSN : 2620 - 4673 (online)

Website : http://jurnal.untan.ac.id/index.php/JPLP2KM

bayam sebelumnya hanya dilakukan antar anggota KWT yang lain melalui kegiatan-kegiatan pengajian, kelompok Yasinan, PKK serta pada saat ada acara-acara tertentu seperti lomba cipta menu dan berbagai pameran yang diadakan atas undangan dari Pemko Palangka Raya. Diharapkan melalui pelatihan dan pendampingan terhadap KWT Petuk Ketimpun ini, dapat meningkatkan pendapatan petani sayuran di Kelurahan tersebut. Tujuan khusus dari pengabdian ini adalah memberikan pelatihan pembuatan keripik sayuran menggunakan vacuum frying, memfasilitasi penggunaan mesin vacuum frying, membantu KWT sayuran untuk mengkaji kelayakan usaha pembuatan keripik sayuran dengan vacuum frying, serta melakukan pendampingan usaha.

\section{METODE}

Pelaksanaan kegiatan pemberdayaan KWT di Kelurahan Petuk Ketimpun Kec. Jekan Raya Kota Palangka Raya dilaksanakan pada tahun 2018. Mitra pada kegiatan ini adalah KWT Bunga Tanjung dan Anugerah. Pemilihan khalayak sasaran didasarkan atas pertimbangan bahwa daerah Petuk Katimpun merupakan salah satu sentra penghasil dan pemasok sayuran di Palangka Raya serta dari hasil diskusi awal dengan PPL setempat Sunainah, S.Pt diketahui bahwa petani mempunyai permasalahan dengan produk sayurannya ketika panen raya dimana sayuran tidak bisa diserap oleh pasar. Pelaksanaan kegiatan meliputi penyuluhan, pelatihan dan praktek secara langsung pembuatan keripik berbahan baku sayur-sayuran. Kegiatan dilakukan melalui tahapan-tahapan sebagai berikut: 1) sosialisasi program, dilakukan pada awal kegiatan terhadap target mitra. Dari diskusi program diketahui bahwa mitra sudah mempunyai usaha komersial keripik sayuran dengan pengolahan digoreng biasa (deep frying) tetapi kurang laku dikarenakan ketatnya persaingan. Usaha keripik sejenis sudah banyak di Palangka Raya. Dalam sosialisasi disepakati antara tim pengabdian dengan mitra untuk menerapkan teknologi vacuum frying sebagai metode pengolahan berbagai keripik sayuran tersebut 2) penyuluhan, dengan cara komunikasi langsung dan diskusi secara interaktif. Diskusi dilakukan dalam bentuk presentasi oral disertai dengan penggunaan viasualisasi gambar sehingga mempermudah pemahaman dan menarik bagi mitra 3 ) pelatihan pembuatan keripik sayuran menggunakan vacuum frying serta 4) pembinaan dan pendampingan kelompok usaha keripik sayuran, meliputi pendampingan dalam perolehan SPP-IRT serta pembinaan dalam mengakses pasar baik secara langsung maupun tidak langsung. 


\section{HASIL DAN PEMBAHASAN}

Petuk Ketimpun mempunyai luas wilayah 59,75 $\mathrm{km}^{2}$. Kelurahan ini mempunyai agroekosistem lahan kering dataran rendah dengan ketinggian 25-30 m dpl. Secara administratif, Petuk Ketimpun berbatasan langsung sebelah utara dengan Kelurahan Marang, sebelah selatan dengan Kelurahan Tumbang Rungan, sebelah barat dengan Kelurahan Bukit Tunggal serta sebelah timur berbatasan langsung dengan sungai Rungan dan Kabupaten Pulang Pisau. Lokasi kelurahan ini berada di pinggiran kota Palangka Raya sehingga akses menuju desa ini relatif lebih mudah. Perjalanan sampai ke desa tersebut dapat ditempuh menggunakan jalan darat melalui jalan trans Kalimantan yang menghubungkan kota Palangka Raya dengan kabupatenkabupaten lainnya di Kalimantan Tengah. Dalam sebarannya, desa/kalurahan Petuk Ketimpun mempunyai pola persebaran memanjang (linier) yaitu pola desa yang mengikuti jalan. Desa terletak di sebelah kiri/kanan jalan raya atau jalan umum. Pola tersebut dimaksudkan untuk mendekati prasarana transportasi seperti jalan untuk berpergian ke tempat lain jika ada keperluan di samping untuk mempermudah penyerahan barang dan jasa.

Kelembagaan petani sangat berkontribusi dalam meningkatkan kemandirian dan kesejahteraan petani (Anantanyu, 2011). Kemampuan kelembagaan kelompok tani yang ada di Kelurahan Petuk Katimpun, untuk dapat meningkatkan kesejahteraan masyarakat secara umum dan anggota kelompok tani secara khusus, masih dapat dioptimalkan. Hal ini dikarenakan dari keseluruhan kelompok tani yang terdata di desa Petuk katimpun yaitu sebanyak 10 kelompok tani, hanya terdapat 5 kelompok yang aktif melakukan berbagai kegiatan, diantaranya kelompok: Tunas Mekar; Harapan Baru; Global Hampapak Rindu; Bunga Tanjung; dan Wargo Mulyo serta 1 Gapoktan Karya Mandiri (Sunainah, 2017). Oleh karena itu penguatan kelembagaan kelompok tani di desa Petuk Katimpun, baik terhadap kelompok tani yang belum aktif maupun yang aktif, perlu ditingkatkan. Berdasarkan informasi dari Petugas Penyuluh Lapangan (PPL) Kelurahan Petuk Ketimpun Sunainah, S.Pt., secara umum kelompok tani di wilayah tersebut cukup dinamis (suka berkelompok, berdiskusi dan selalu terbuka terhadap hal-hal baru), sehingga diharapkan kedinamisan kelompok tani tersebut dapat membantu mempercepat proses adopsi dan difusi inovasi teknologi, khususnya teknologi yang berkaitan dengan hortikultura. Terkait dengan transfer teknologi vacuum frying belum pernah dilakukan sama sekali di Petuk Katimpun.

Hasil evaluasi awal yang dilakukan terhadap KWT menunjukkan bahwa 100\% responden (anggota mitra) tidak mengetahui teknologi vacuum frying, meskipun 14,2\% mengetahui 
ISSN : 2620 - 4665 (print)

ISSN : 2620 - 4673 (online)

Website : http://jurnal.untan.ac.id/index.php/JPLP2KM

adanya olahan keripik buah di pasaran yang diolah dengan vacuum frying namun tidak mengetahui proses pengolahannya. Hampir semua anggota mitra (92\%) berminat untuk mengembangkan usaha keripik sayur. Olahan keripik seperti keripik pisang, singkong, bayam dan ikan seluang sudah pernah dilakukan oleh $46 \%$ anggota mitra dengan penggorengan biasa (deep frying). Keripik yang pernah dibuat tersebut $60 \%$ dijual di lingkungan sekitar ataupun kenalan. Dari produk yang dijual hanya $40 \%$ yang dikemas menggunakan label namun kesemuanya belum menggunakan pelabelan seperti yang disyaratkan. Semua anggota mitra juga belum mengetahui dan memahami pentingnya SPP-IRT.

Penyuluhan dan pelatihan dilakukan di salah satu rumah warga di Jl. Tjlilik Riwut KM 11 dengan pertimbangan kapasitas listrik yang memadai untuk pengoperasian alat vacuum frying. Kegiatan dihadiri oleh Sekretaris Lembaga Penelitian dan Pengabdian Pada Masyarakat Prof. Dr. Ir. Saputera, M.Si mewakili Universitas Palangka Raya, sekretaris Lurah Sartono mewakili Lurah Petuk Katimpun, PPL Petuk Katimpun serta anggota KWT Bunga Tanjung dan Anugerah. Untuk memotivasi mitra dalam memproduksi keripik sayur, diberikan bantuan berupa 1 (satu) set alat vacuum frying beserta peralatan lainnya peralatan kepada mitra, yang secara simbolis disampaikan oleh Sekertaris LPPM UPR Prof. Dr. H. Saputera, M.Si. Bantuan ini dapat digunakan sebagai modal awal untuk memproduksi keripik sayur. Narasumber penyuluhan adalah Ir. Wijantri Kusumadati, MP (Prodi Teknologi Industri Pertanian UPR) dengan materi Pengenalan Alat Vacuum frying serta Strategi Perolehan Sertifikat P-IRT yaitu mengenai pengertian dan dasar hukum pentingnya SPP-IRT, higienitas proses produksi maupun lingkungan yang merupakan salah satu syarat untuk menperoleh sertifikat P-IRT. Pembuatan Keripik Sayur serta Pengemasan dan Pelabelan merupakan materi yang disampaikan oleh Dr. Hastin Ernawati Nur Chusnul Chotimah, MP (Prodi Agroteknologi UPR), sementara itu Analisis Usaha dan Manajemen Pemasaran yang meliputi perhitungan terhadap biaya produksi meliputi Analisis Biaya dan Pendapatan (Net Profit Margin) serta cara menghitung Break Event Point untuk usaha mitra disampaikan oleh Dr. Ir. Eka Nor Taufik, MP (Prodi Agribisnis UPR) (Gambar 1). Peserta kegiatan penyuluhan menunjukkan antusiasme dan tanggapan positif dengan banyaknya tanggapan yang disampaikan. Sebagian peserta bahkan merasa penasaran dengan metode vacuum dan ingin segera menerapkan dalam usaha keripik mereka. Mereka juga mengharapkan adanya tindak lanjut dari kegiatan penyuluhan tersebut dalam bentuk pelatihan dan pendampingan. 

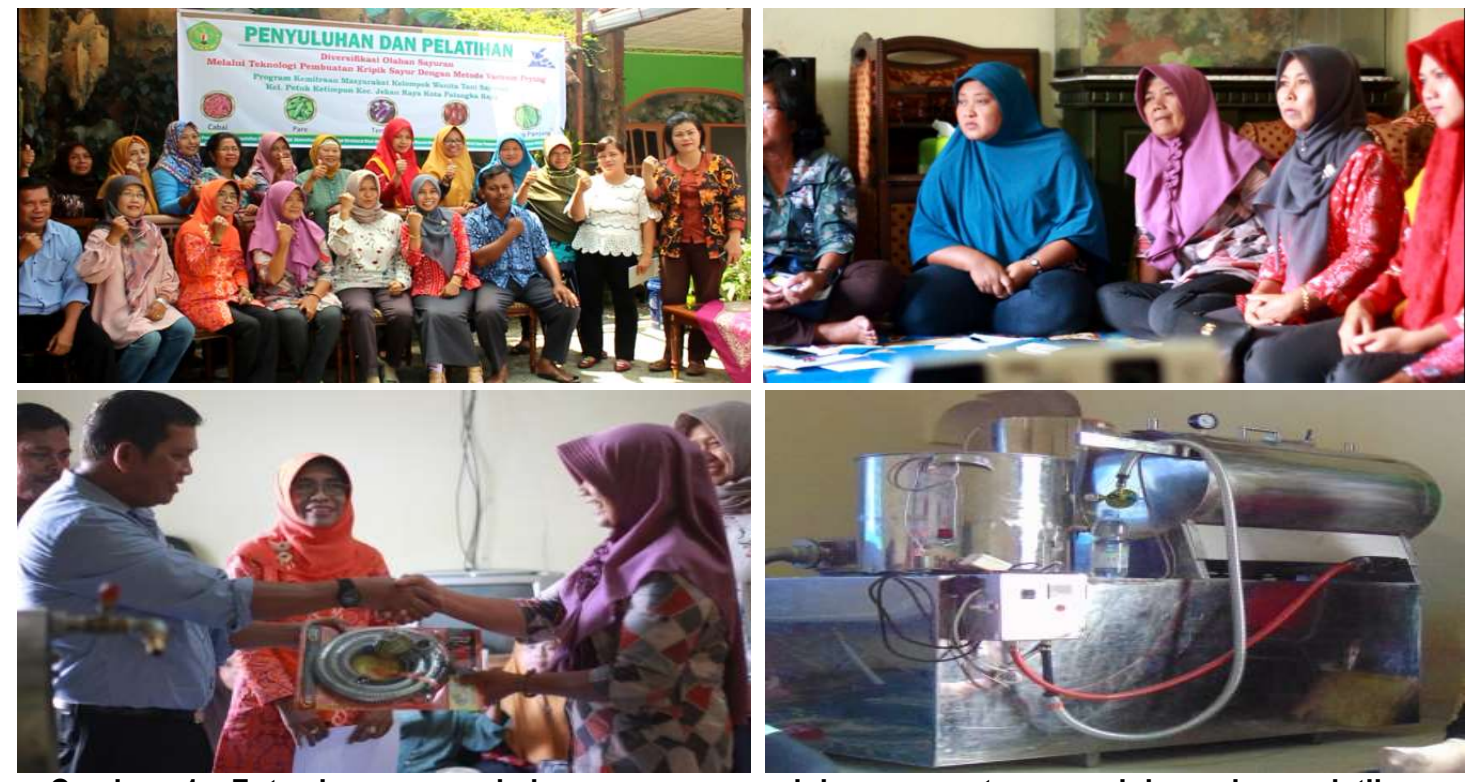

Gambar 1. Foto bersama sebelum acara penyuluhan, peserta penyuluhan dan pelatihan, penyerahan simbolis vacuum frying dan 1 (satu) set bantuan alat vacuum frying

Pelatihan pembuatan keripik sayuran menggunakan vacuum frying dilakukan pada hari berikutnya untuk memberikan keterampilan praktis serta transfer teknologi kepada mitra. Teknologi vacuum frying sebenarnya merupakan teknologi sederhana hanya saja dalam pengoperasiannya memerlukan tahapan-tahapan yang berurutan (spesifikasi alat vacuum frying pada Tabel 1). Setiap tahap proses produksi keripik sayur akan berpengaruh terhadap kualitas keripik sayur yang dihasilkan. Prinsip kerja vacum frying adalah menghisap kadar air dalam sayuran dan buah dengan kecepatan tinggi agar pori-pori daging buah-sayur tidak cepat menutup, sehingga kadar air dalam buah dapat diserap dengan sempurna. Tahapan-tahapan dalam proses pelatihan meliputi a) pengenalan alat (vacuum, spinner dan sealer) dan SOP penggunaan, penanganan dan pemeliharaan alat b) penanganan awal bahan baku sayuran c) persiapan alat vacuum frying d) penirisan keripik sayur yang sudah matang pada spinner serta e) pengemasan dan pelabelan produk (Gambar 2). 
ISSN : $2620-4665$ (print)

ISSN : 2620 - 4673 (online)

Website : http://jurnal.untan.ac.id/index.php/JPLP2KM

Tabel 1. Spesifikasi alat vacuum frying

\begin{tabular}{lc}
\hline \multicolumn{1}{c}{ Uraian } & Model \\
\hline Kapasitas (kg/masukan/proses) & $3 \mathrm{~kg}$ \\
Lama proses (menit) & $55-75$ \\
Type & Horizontal \\
Bahan bakar & LPG dengan kontrol suhu otomatis \\
Pendingin & Sirkulasi air \\
Volume minyak goreng (liter) & 30 liter \\
Kebutuhan minyak liter/jam & 0,1 \\
Kebutuhan daya (watt) & 1100 watt \\
Instalasi listrik rumah minimum & 1300 watt \\
Dimensi bak air & $122 \times 122 \times 28,5$ \\
Dimensi total & $134 \times 122 \times 144$ \\
Volume pada waktu diangkut $\left(\mathrm{cm}^{3}\right)$ & $130 \times 130 \times 50$ \\
Kelengkapan & Spinner dan hand sealer \\
Garansi & 1 tahun \\
\hline
\end{tabular}

Hasil evaluasi pada akhir program pemberdayaan masyarakat tersebut menunjukkan bahwa sebesar $70 \%$ mitra sudah memahami pengoperasian alat vacuum frying, sedangkan $30 \%$ masih agak memahami. Peserta yang masih agak memahami pengoperasian alat dikarenakan takut dengan gas, listrik dan penggunaan tabung vacuum. Ketakutan ini terutama karena faktor usia peserta .Walaupun demikian 100\% anggota mitra menginginkan memproduksi keripik sayur dan memasarkannya. Untuk meningkatkan pemahaman operasional alat maka tim melakukan pendampingan beberapa kali dalam memproduksi keripik sayur hingga anggota mitra memahami pengoperasian alat. Produk keripik yang paling disukai responden adalah keripik tomat (50\%), keripik ketimun (30\%), dan keripik labu (20\%). Kendala utama yang dirasakan memberatkan mitra dalam produksi keripik sayur adalah kekhawatiran dalam pemasaran karena mahalnya harga jual (60\%). Salah satu cara untuk mengatasi kekhawatiran tersebut adalah dengan memperoleh sertifikat SPP-IRT agar jangkauan pemasaran dapat menembus toko oleh-oleh hingga supermarket yang mempunyai pangsa pasar menengah ke atas. 


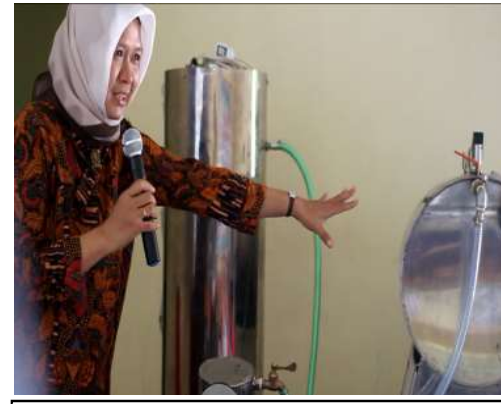

Pengenalan alat

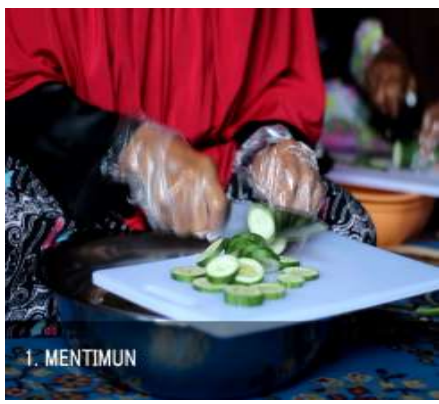

Penanganan bahan baku mentimun

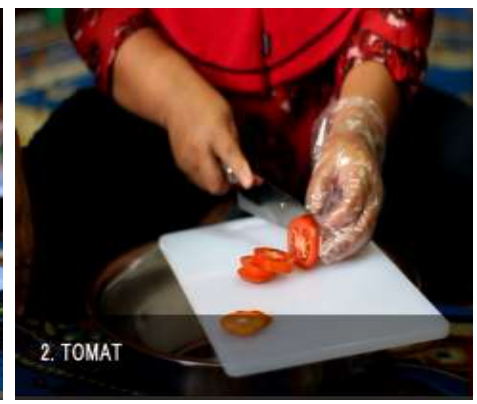

Penanganan bahan baku tomat

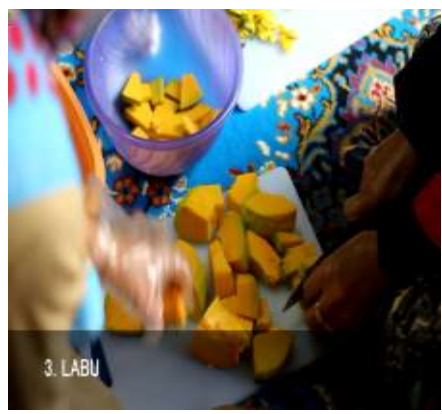

Penanganan bahan baku labu kuning

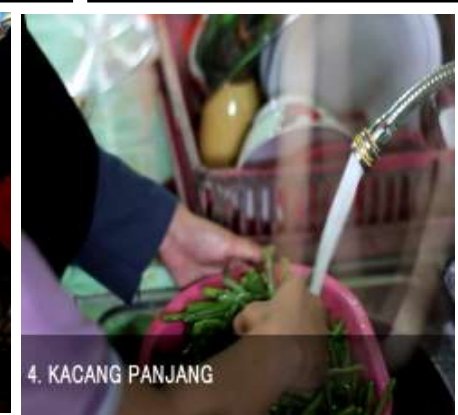

Penanganan bahan baku kacang panjang

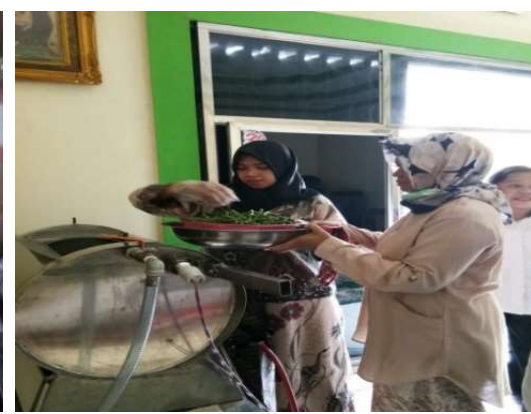

Penggorengan pada mesin vacuum frying frying

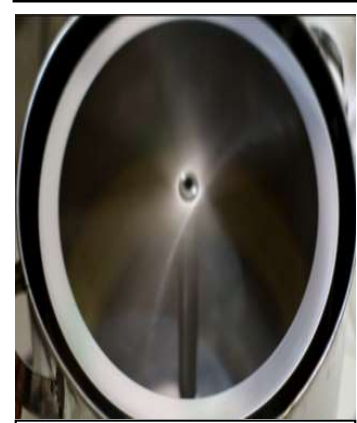

Penirisan spinner
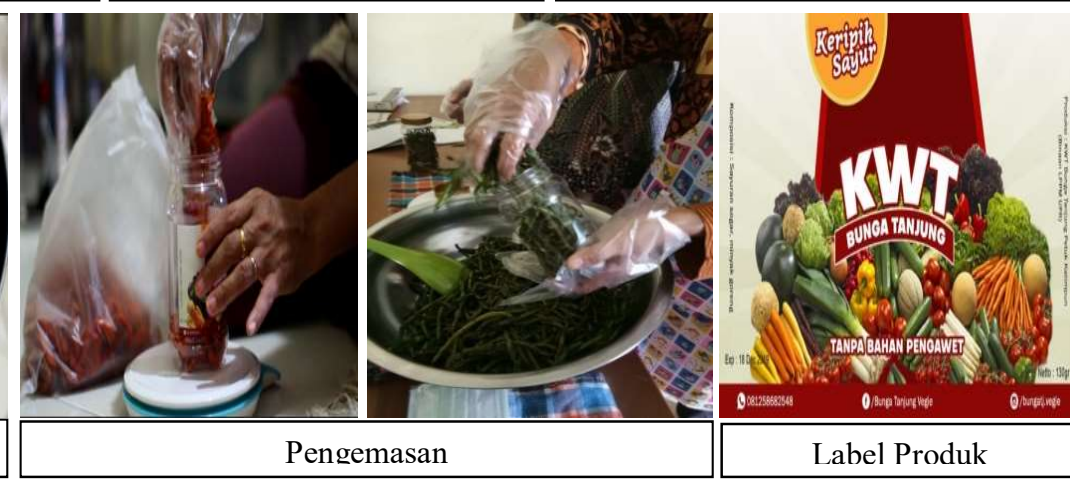

Pengemasan

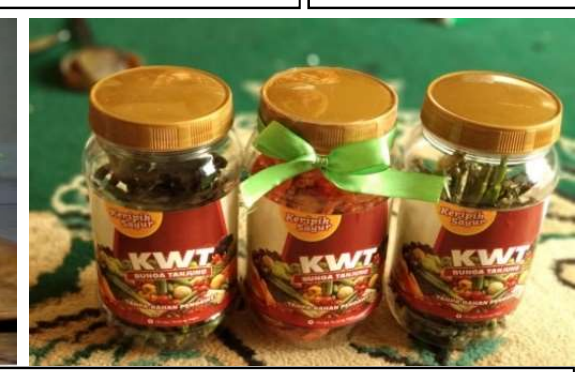

Produk Keripik Sayur dengan Merk KWT Bunga Tanjung

Gambar 2. Foto pada pelatihan pembuatan keripik sayur menggunakan vacuum frying. 
ISSN : $2620-4665$ (print)

ISSN : 2620 - 4673 (online)

Website : http://jurnal.untan.ac.id/index.php/JPLP2KM

Sistem pemasaran merupakan faktor penting dalam kegiatan suatu industri. Keberhasilan suatu produksi tidak akan berarti jika tidak didukung oleh strategi pemasaran yang tepat. Sebagai langkah awal pemasaran sebelum diperolehnya sertifikat SPP-IRT, pendampingan pemasaran dilakukan masih secara tidak langsung. Pada sistem tidak langsung ini adalah dengan menyampaikan informasi produk melalui instagram mitra dengan ID @bungatj.vegie dan facebook bunga tanjung veggie. Tim juga memperkenalkan produk ke lingkungan kampus melalui aplikasi Whatsapp ataupun dengan memberikan sampel produk secara cuma-cuma sebagai tester. Secara tidak langsung beberapa anggota mitra juga telah mengenalkan produk keripik sayur dari mulut ke mulut kepada ibu-ibu di sekitar lingkungan rumah, sekolah, kantor, maupun saudara. Produk keripik sayur KWT Bunga Tanjung juga telah diikut sertakan pada Pameran dalam rangka Hari Jadi Kota Palangka Raya yang berlangsung dari tanggal 24 - 28 Agustus 2018 di Lapangan Sanaman Mantikei pada stand Dinas Pertanian dan Ketahanan Pangan Kota Palangka Raya sebagai ajang promosi. Promosi juga dilakukan media masa Kalteng Pos yang terbit pada tanggal 14 Agustus 2018 dengan tajuk "LPPM UPR Beri Pelatihan KWT" serta pada laman youtube https://www.youtube.com/watch?v=laPOYLqgdU

Sertifikat Produk Pangan Industri Rumah Tangga (SPP-IRT) adalah ijin edar produk olahan yang diproduksi oleh IKM untuk dipasarkan secara lokal. ljin ini dikeluarkan oleh Dinas Penananam Modal dan Pelayanan Terpadu Satu Pintu Kota Palangka Raya yang berlaku selama 5 tahun sejak tanggal penerbitan dan dapat diperpanjang. ljin SPP-IRT penting karena merupakan jaminan bahwa usaha makanan atau minuman rumahan yang dijual memenuhi standar keamanan makanan. Ijin SPP-IRT hanya untuk olahan pangan yang beresiko rendah. Menurut UU RI Tahun 2012 tentang Pangan, keamanan pangan adalah kondisi dan upaya yang diperlukan untuk mencegah pangan dari kemungkinan cemaran biologis, kimia, dan benda lain yang dapat mengganggu, merugikan, dan membahayakan kesehatan manusia serta tidak bertentangan dengan agama, keyakinan, dan budaya masyarakat sehingga aman untuk dikonsumsi. Makanan yang aman merupakan persyaratan yang penting dan mutlak yang harus ada pada setiap jenis makanan dan minuman yang dikonsumsi. Pelaku usaha memainkan peranan yang sangat penting dalam mengupayakan makanan dan minuman tersebut memenuhi standar kesehatan sehingga layak konsumsi. 
Sebagai langkah awal pendampingan perolehan sertifikasi SPP-IRT keripik sayur produksi mitra, tim telah memfasilitasi Penyuluhan Keamanan Pangan (PKP) dari Dinas Kesehatan Kota Palangka Raya, dengan nara sumber : 1) Dra. Hj. Agustinawati U., Apt. M.Si; 2) Ahmad Sofyan Apriady, S.Farm., Apt., dan 3) Gina Fatiah, S.Farm., Apt. Materi yang disampaikan pada mitra pada PKP meliputi keamanan pangan, Peraturan Perundangan Pangan, Hygien dan Sanitasi, bahan tambahan pangan, cara produksi yang baik untuk IRT serta label dan kemasan. Penyuluhan Keamanan Pangan ini selain diikuti oleh anggota KWT Bunga Tanjung juga diikuti oleh 3 orang anggota KWT Lestari Desa Kanamit Barat, Kecamatan Maliku, Kabupaten Pulang Pisau (Gambar 3). Sertfikat PKP ini merupakan syarat mutlak untuk memperoleh sertifikat SPP-IRT. Dengan diperolehnya sertifikat PKP oleh seluruh anggota KWT Bunga Tanjung akan memberikan kemudahan untuk mengembangkan usaha yang selama ini sudah dilakukan oleh sebagian anggota mitra maupun yang akan merintis usaha.
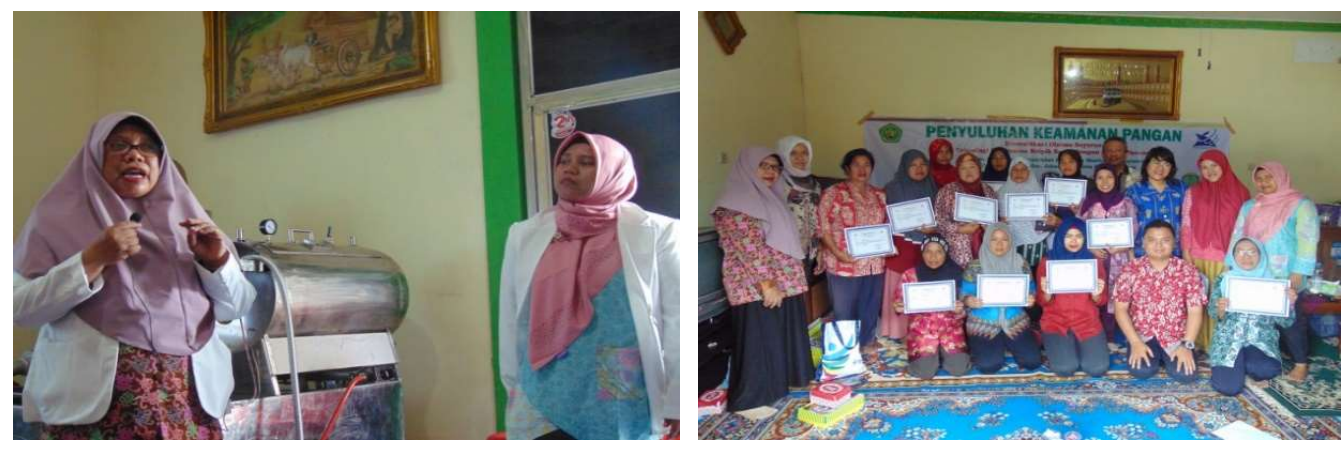

Narasumber dari Dinas Kesehatan Kota Palanoka Rava
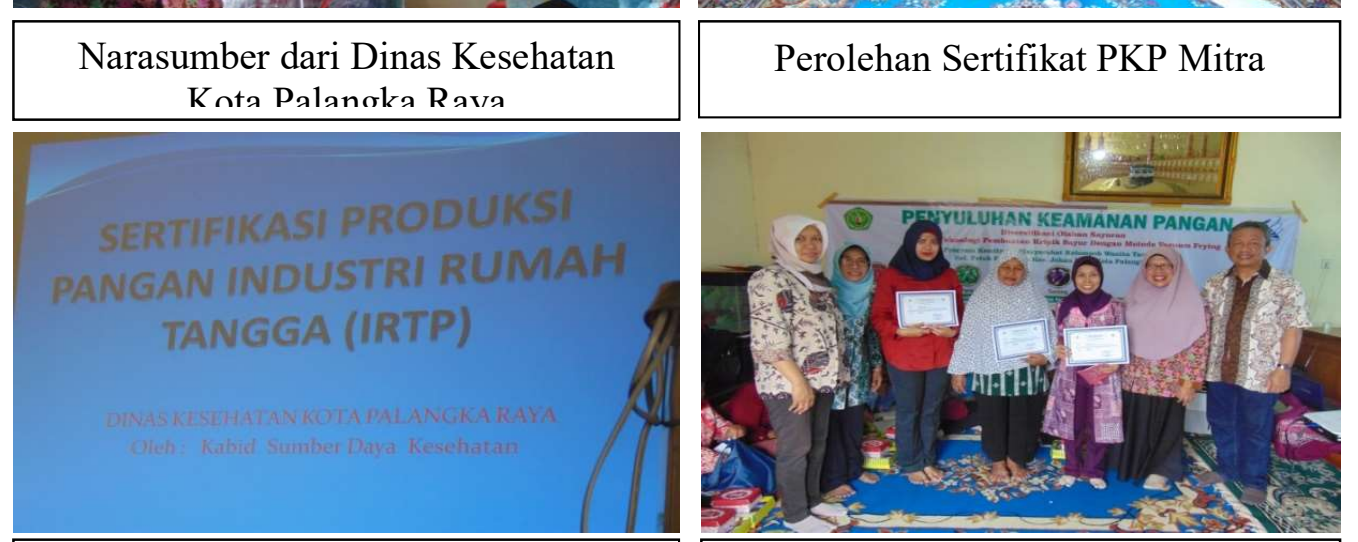

Salah satu materi penvuluhan PKP

Peserta penvuluhan terbaik

Gambar 3. Foto kegiatan Penyuluhan Keamanan Pangan (PKP) dari Dinas Kesehatan Kotamadya Palangka Raya 
ISSN : $2620-4665$ (print)

ISSN : 2620 - 4673 (online)

Website : http://jurnal.untan.ac.id/index.php/JPLP2KM

Dari analisis program pemberdayaan secara keseluruhan, terdapat beberapa faktor pendukung dan penghambat. Faktor pendukung diantaranya mitra mempunyai semangat berusaha yang besar, mau mengembangkan usahanya dan selalu terbuka terhadap hal-hal baru. Beberapa kendala dalam penerapan ipteks diantaranya ketergantungan anggota KWT yang tinggi terhadap inisiatif kepengurusan. Ketergantungan yang dimaksud seperti dalam hal pengambilan keputusan produksi, dan pemasaran hasil, sehingga perlu pembagian tugas dan kewenangan untuk anggota. Kurangnya kepercayaan diri dalam mengoperasikan alat vacuum frying juga merupakan suatu permasalahan yang perlu diatasi dengan memberikan motivasi kepada mitra serta melakukan pendampingan dengan harapan tercipta keberlanjutan usaha untuk meningkatkan kesejahteraan masyarakat. Pengurusan sampai dengan penerbitan SPPIRT membutuhkan tahapan yang cukup lama. Hal tersebut dikarenakan dalam penerbitan sertfikat SPP-IRT melibatkan dua instansi pemerintah kota yang berbeda sehingga memerlukan koordinasi yang cukup lama.

\section{SIMPULAN DAN REKOMENDASI}

Dari hasil evaluasi penerapan ipteks dan analisis program pemberdayaan masyarakat dapat disimpulkan bahwa teknologi vacuum merupakan hal yang baru di KWT Petuk Katimpun, walaupun demikian mitra mempunyai semangat dan kepercayaan diri yang tinggi untuk mengembangkan usaha keripik sayur menggunakan alat tersebut. Hal tersebut dibuktikan bahwa pada saat akhir program sebagian besar mitra sudah memahami pengoperasian alat vacuum frying dan hampir semua mitra ingin memproduksi serta memasarkan keripik sayur tersebut. Mitra mempunyai keyakinan bahwa teknologi vacuum mempunyai keunggulan dan dapat digunakan sebagai salah satu usaha yang dapat meningkatkan pendapatan mereka. Apabila SPP-IRT sudah diperoleh, rekomendasi dalam rangka perbaikan, pengembangan dan daya saing produk keripik sayuran yang sudah dihasilkan diantaranya penambahan varian jenis sayuran sebagai bahan baku dan melakukan promosi lebih intensif untuk meningkatkan penjualan dan brand image masyarakat pada produk KWT Bunga Tanjung. Apabila permintaan produk sudah stabil, perlu diimbangi dengan pengembangan SDM tentang sistem manajemen keuangan, dan atau pemasaran yang efektif. 


\section{UCAPAN TERIMAKASIH}

Ucapan terimakasih disampaikan kepada Direktorat Jenderal Penguatan Riset dan Pengembangan Kementrian Ristek dan Pendidikan Tinggi yang telah membiayai kegiatan pengabdian kepada masyarakat melalui Hibah Program Kemitraan Masyarakat Dana BOPTN Nomor : 017/SP2H/DRPM/2018.

\section{DAFTAR PUSTAKA}

Anantanyu S, 2011. Kelembagaan Petani : Peran dan Strategi Pengembangan Kapasitasnya, SEPA Vol 7 (2) : 102-109

Hambali, Suryani A, dan Purnama W. 2005. Membuat Keripik Sayur. Penebar Swadaya. Depok

Sucihartiningsih, Kuswardinah A, Fafurida. 2015. IbM Untuk Sayur Pengolahan Keripik Terong dan Wortel Di Desa Lanjan Kecamatan Sumowono Kabupaten Semarang. Rekayasa Vol. 13 No. 2

Sunainah. 2017. RKTP (Rencana Kerja Tahunan Penyuluh). Dinas Ketahanan Pangan dan Pertanian Kota Palangka Raya. 